\title{
The Utilization of Auto-Inducible Plyb Promoter and Media Optimization for Cell Density-Dependent Expression of Recombinant Thermoalkalophilic Xylanase in Bacillus subtilis DB104
}

\author{
HANIYYA, DINI ACHNAFANI, MARIA ULFAH, NIKNIK NURHAYATI, AND IS HELIANTI* \\ Center for Bioindustrial Technology-Agency of Assessment and Application of Technology (BPPT), Building 611/614, \\ LAPTIAB-BPPT, PUSPIPTEK Area, Setu, South Tangerang, 15314, Indonesia.
}

\begin{abstract}
Strong promoters are one of the fundamental aspects to increase the level of gene expression, and one of approach to improve the recombinant enzyme productivity so that the efficiency of production cost for enzyme production in industrial scale can be reached. Here we assessed the application of a cell density-dependent promoter and media optimation to promote cell growth and protein expression of Bacillus subtilis without excess usage of inducers. An auto-inducible Pylb promoter that is potential to provide inducer-free enzyme production was cloned and introduced into xylanase recombinant system in B. subtilis DB104 by PCR cloning and protoplast transformation. A 200 bp target gene was successfully inserted in between $x y n C M 1$ ORF -coding for $B$. halodurans CM1 xylanase- and its native promoter sequence at the upstream region. The disruption of the native promoter was intended to replace the native promoter with Pylb. Recombinant xylanase gene under Pylb was successfully expressed in B. subtilis DB104 and the enzyme was produced at stationary phase. Different media with various concentrations of glucose and nitrogen were used to optimize recombinant xylanase expression. It achieved a higher level of xylanase expression compared to wild-type Bacillus and recombinant xylanase with native promoter expressed in B. subtilis in media containing a 2-fold recipe of LB media thus leads to increase cell density and xylanase expression $\left(81.461 \mathrm{U} \mathrm{mL}^{-1}\right)$.
\end{abstract}

Key words: auto-inducible, Bacillus subtilis DB104, Pylb, xylanase

Promotor yang kuat adalah salah satu aspek mendasar untuk meningkatkan tingkat ekspresi gen, dan salah satu pendekatan untuk meningkatkan produktivitas enzim rekombinan sehingga efisiensi biaya produksi enzim pada skala industri dapat tercapai. Di dalam studi ini aplikasi promotor yang bergantung pada kepadatan sel tanpa penggunaan induser secara berlebihan dari induser dan optimasi media untuk mendorong pertumbuhan sel dan ekspresi enzim xilanase di Bacillus subtilis telah dilakukan. Promotor Pylb yang auto inducible berpotensi untuk menyediakan produksi enzim bebas-induktor telah dikloning dan dimasukkan ke dalam sistem rekombinan xilanase di B. subtilis DB104 via kloning PCR dan transformasi protoplas. Gen target sepanjang 200 bp berhasil disisipkan di antara xynCM1 ORF -yang mengkodekan $B$. halodurans CM1 xylanase- dan promotor asli. Gangguan promotor asli dimaksudkan untuk menggantikan promotor asli dengan promoter Pylb. Gen xilanase rekombinan di bawah Pylb berhasil diekspresikan dalam B. subtilis DB104 dan enzim diproduksi pada fase stasioner. Media yang berbeda dengan berbagai konsentrasi glukosa dan nitrogen digunakan untuk mengoptimalkan ekspresi xilanase rekombinan. Tingkat ekspresi xilanase yang lebih tinggi daripada B. subtilis non rekombinan ataupun $B$. subtilis rekombinan yang mengandung gen xilanase alkalotermofilik dengan promoter asli ditemukan di dalam media yang mengandung resep LB 2 kali lipat dari media LB sehingga mengarah pada peningkatan kepadatan sel dan ekspresi xilanase $\left(81,461 \mathrm{U} \mathrm{mL}^{-1}\right)$.

Kata kunci: auto-inducible, Bacillus subtilis DB104, Pylb, xilanase

In gene expression, promoters are known as one of the key factors to have an important role in defining where the gene transcription starts. It is in the upstream on an open reading frame near the transcription site starts and comprises a set of sequence that has recognizable patterns. The strength of the promoters would likely affect RNA polymerase binding and therefore can contribute to the enhancement of target gene expression (Mekler et al. 2012; Einav and Philipp

*Corresponding author: Phone: +62-21-7560694; Fax: +6221-7566922; Email: is.helianti@bppt.go.id
2019). It is suggested that choosing the promoters that are suitable for our target genes should be done wisely to obtain the desired level of expression (Schumann 2007; Wenzel et al. 2011; Einav and Philipp 2019).

There are many types of promoters used in heterologous protein expression system of recombinant host from Bacillus genus, that is constitutive promoters, inducer-specific promoters, and auto-inducible promoters (Schumann 2007; Yu et al. 2015), among which induced-promoters are the most commonly used to date. However, these inducible promoters are not cost-efficient in the context of 
industrial application because of the requirement of certain chemicals and compounds to be added in the process. For example Pxyl, one of the most used in industry, needs xylose as its inducers (Yu et al. 2015; Meyers et al. 2019). Native inducible-promoter of genes encoding enzymes also needs its substrate to produce high-level protein production, such as xylan for xylanase (Gupta et al. 2008; Ulfah et al. 2011; Helianti et al. 2018) and skim milk for protease (Ulfah et al. 2011; $\mathrm{Cu}$ et al. 2015). Since the usage of constitutive promoter can generate toxic protein that can be lethal for the host, this leads us to consider the advantage of auto-inducible promoters which can ideally facilitate efficient production process at low cost with an optimum condition (Yu et al. 2015; Meyers et al. 2019; Trung et al. 2019).

Several highly-efficient non-inducible promoters in Bacillus subtilis had been identified by $\mathrm{Yu}$ et al. (2015), among them was Pylb which strongly promoted $\beta$-galactosidase expression and showed significant superiority from the rest of selected promoters. This promoter was not only actively expressing reporter gene bga $\mathrm{B}$ during stationary phase but also boosting a higher activity of $\beta$-galactosidase up to 5000 times. Hence, this $\mathrm{P} y l b$ promoter is potential to be used for overexpressing other recombinant gene product with no inducer needed (Yu et al. 2015) especially one which utilizes $B$. subtilis as cell factory.

B. subtilis DB104 is a Gram-positive bacterium that is generally recognized as a safe (GRAS) nontoxic organism (Westers et al. 2004; Watzlawick and Altenbuchner 2011). Along with members of Bacillus genera, its ability to secrete protein into extracellular sphere and grow in mesophilic condition at $37^{\circ} \mathrm{C}$ in minimum media with various carbon and nitrogen source (Wenzel et al. 2011; Mageshwaran et al. 2014] has attracted scientists to use them as recombinant host in large-scale production as they cover more than onethird of industrial enzyme (Meissner et al. 2015; Watzlawick and Altenbuchner 2019]. On top of that, $B$. subtilis DB104 has alkaline protease gene deleted ( $\triangle a p r A 3)$, allowing them to secrete less protease and therefore the target protein will have lower denaturation risk (Kawamura and Doi 1984) and it also might be more suitable to express genes from the same Gram-positive bacteria than E. coli.

Our recent work has been focused on utilize native promoter for expression of xynCM1 gene in B. subtilis DB104. Whilst it could enhance the enzyme production in the host compared to the native $B$. subtilis DB104 (Haniyya et al. 2019), the productivity of recombinant clones was still almost 4 times lower than the wild-type $B$. halodurans CM1. The expenses of using xylan or raw corncob as inducers also rise concerns both in terms of cost-efficiency and convenience of upstream and downstream processes.

The utilizing an auto-inducible promoter from $B$. subtilis is very much necessary to upgrade the recombinant protein production system in B. subtilis DB104. Hence, the current study aimed to clone and utilize Pylb promoter for cell density-dependent expression of thermoalkalophic xylanase originally from $B$. halodurans and the strategy with optimized media. Media optimization was also a highlight in our study since it was very critical for cell growth and therefore played as an important factor in determining $\mathrm{P} y l b$ promoter efficiency.

\section{MATERIALS AND METHODS}

\section{Strains, Cultivation, and DNA Extraction.} Eschericia coli DH5 $\alpha$ was used only as cloning host and $B$. subtilis DB104 was engineered for subcloning and recombinant protein production. The wild-type strains were grown in default condition at $37^{\circ} \mathrm{C}, 150$ rpm for overnight in LB media ( $0.5 \%$ yeast extract, $1 \%$ $\mathrm{NaCl}$, and $1 \%$ peptone). The recombinant strains were also cultivated in stated condition using LB media with respective antibiotics $\left(100 \mu \mathrm{g} \mathrm{mL}^{-1}\right.$ ampicillin and $5 \mu \mathrm{g}$ $\mathrm{mL}^{-1}$ erythromycin) unless stated otherwise.

Whole genomic DNA of B. subtilis DB104 was extracted using extraction kit from Thermo Fisher Scientific. According to its protocol for Gram-positive bacteria, an overnight culture was collected and treated with $180 \mu \mathrm{L}$ Gram-positive bacteria lysis buffer which consists of $20 \mathrm{mM}$ Tris- $\mathrm{HCl} \mathrm{pH} \mathrm{8.0,2} \mathrm{mM} \mathrm{EDTA,} \mathrm{and}$ $20 \mathrm{mg} \mathrm{mL}^{-1}$ of lysozyme. After incubation at $37^{\circ} \mathrm{C}$ for $30 \mathrm{~min}, 200 \mu \mathrm{L}$ of Lysis Solution and $20 \mu \mathrm{L}$ of Proteinase $\mathrm{K}$ were added to the suspension to perform cell lysis and protein removal. The sample was incubated at $56^{\circ} \mathrm{C}$ while vortexing to ensure a uniform suspension until the cells were completely lysed (about $30 \mathrm{~min}$ ). To obtain purified genomic DNA, $20 \mu \mathrm{L}$ RNAse was added to the suspension and followed with the addition of $400 \mu \mathrm{L} 50 \%$ ethanol. The prepared lysate was then transferred to the filtered column and washed by Wash Buffer I and Wash Buffer II of each contained pure ethanol. Before DNA elution was performed, the column was spun at maximum speed $(12,000 \times \mathrm{g})$ for $3 \mathrm{~min}$ to dry. Genomic DNA was obtained after a 5-min incubation step with $200 \mu \mathrm{L}$ Elution Buffer. All centrifugation was done at 
$6,000-8,000 \times \mathrm{g}$ except for the drying process.

Isolation of Pylb Promoter. The Pylb promoter was amplified from gDNA of $B$. subtilis DB104 by a set of primers based on work of Yu et al. (2015) but modified for restriction-free cloning by the addition of backbone sequences in $5^{\prime}$ or $3^{\prime}$ overhangs in both primer F1 and R1 (Table 1). Genomic DNA was isolated using GeneJET Genomic DNA Purification Kit [\#K072, Thermo Fisher Scientific, Waltham, USA]. The Pylb gene was amplified by PCR in a $50 \mu \mathrm{L}$ reaction mixture composed of $10 \mu \mathrm{L} 5 \times$ HF Buffer, 1 $\mu \mathrm{L} 10 \mathrm{mM}$ dNTPs, $2.5 \mu \mathrm{L}$ of $10 \mu \mathrm{M}$ forward and reverse primers, $1.5 \mu \mathrm{L} \mathrm{100 \%} \mathrm{DMSO,} 5 \mu \mathrm{L}$ template gDNA, $0.625 \mu \mathrm{L}$ Phusion HiFi DNA Polymerase [Thermo Fisher Scientific, Waltham, USA], and $26.875 \mu \mathrm{L}$ nuclease-free water to bring the total volume of $50 \mu \mathrm{L}$. After a swift initial denaturation of 98 ${ }^{\circ} \mathrm{C}$ for $30 \mathrm{~s}$, amplification was performed in 30 cycles of $10 \mathrm{~s}$ at $98^{\circ} \mathrm{C}, 15 \mathrm{~s}$ at $72{ }^{\circ} \mathrm{C}$, and $30 \mathrm{~s}$ at $72{ }^{\circ} \mathrm{C}$, followed by a final extension at $72{ }^{\circ} \mathrm{C}$ for $5 \mathrm{~min}$ to ensure the fragment elongation. The $256 \mathrm{bp}$ fragment of $\mathrm{P} y l b$ gene was then purified using GeneAid Gel/PCR DNA Fragments Kit [DF100, Geneaid Biotech, New Taipei City, Taiwan] by mixing it with $250 \mu \mathrm{LDF}$ Buffer prior to sample transfer into DF column by centrifugation at $14,000 \times \mathrm{g}$ for $30 \mathrm{~s}$. The wash step with the addition and 1-minute incubation of $600 \mu \mathrm{L}$ Wash Buffer followed and the purified DNA was eluted at last with $50 \mu \mathrm{L}$ Elution Buffer.

Construction of Plasmid for Xylanase Gene Expression with Mega Primer Approach. The recombinant plasmid was constructed through restriction-free cloning by PCR insertion of Pylb gene into pSKE194.natprom-alkxynCM1-inlip as template plasmid. The insertion was occurred between native promoter and $x y n C M 1$ gene to replace upstream region as gene promoter. There were two megaprimers used in the experiment (Fig 1), the purified Pylb as the targeted gene and $x y n C M 1$ gene to assist the annealing process of targeted gene into the template (Ulrich et al. 2012; Mathieu et al. 2014). The assisting-gene were amplified by the method described in previous study (Helianti et al. 2018).

PCR was performed in a $50 \mu \mathrm{L}$ reaction mixture composed of $10 \mu \mathrm{L} 5 \times$ HF Buffer, $1 \mu \mathrm{L} 10 \mathrm{mM}$ dNTPs, $1.5 \mu \mathrm{L} \mathrm{100 \%}$ DMSO, $25 \mathrm{ng}$ plasmid template, $100 \mathrm{ng}$ purified Pylb target gene, $100 \mathrm{ng}$ purified $x y n C M 1$ assisting-gene, $0.5 \mu \mathrm{L}$ Phusion HiFi DNA Polymerase [Thermo Fisher Scientific, Waltham, USA], and $34 \mu \mathrm{L}$ nuclease-free water to bring the total volume of $50 \mu \mathrm{L}$. A quick initial denaturation was performed at $98{ }^{\circ} \mathrm{C}$ for $30 \mathrm{~s}$ and followed by 30 cycles gene amplification

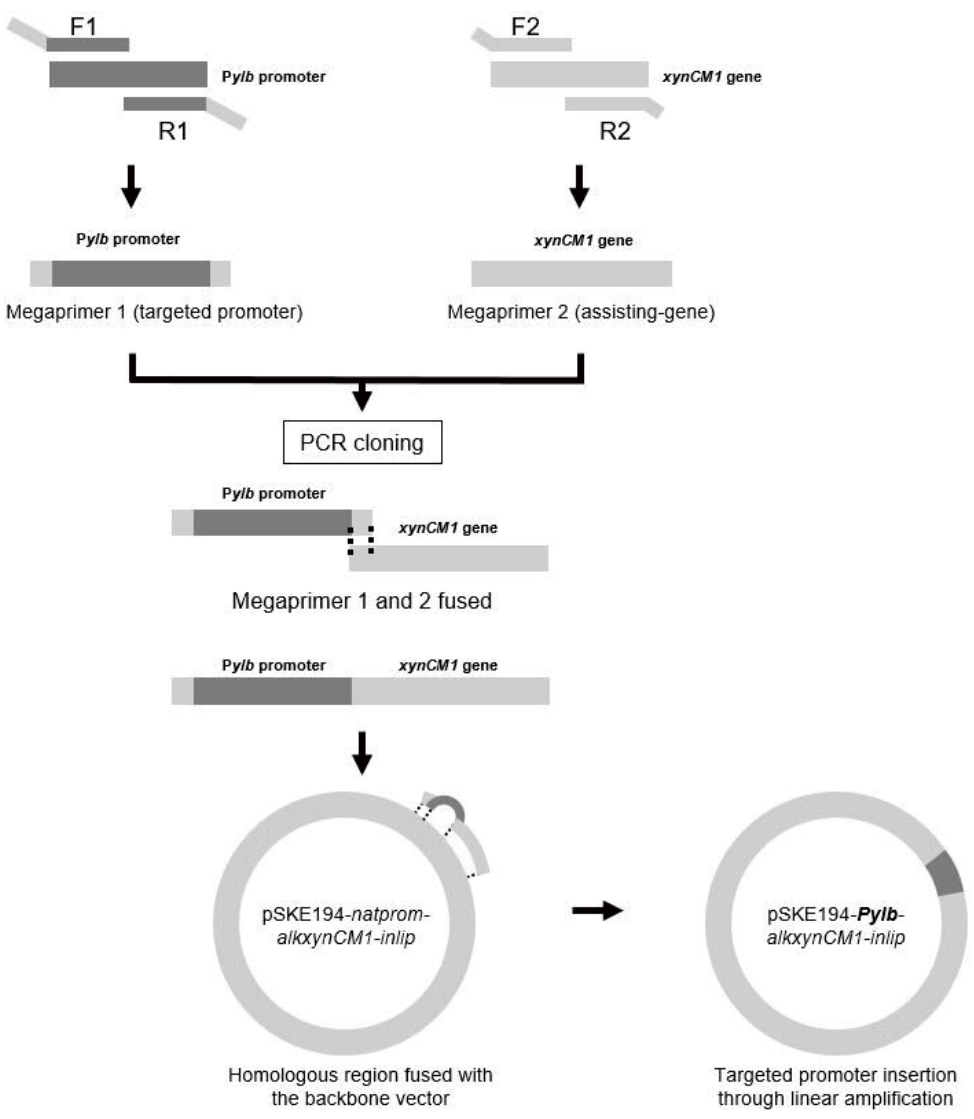

Fig 1 The process of megaprimer-assisted cloning. 
Table 1 List of primers used in the study

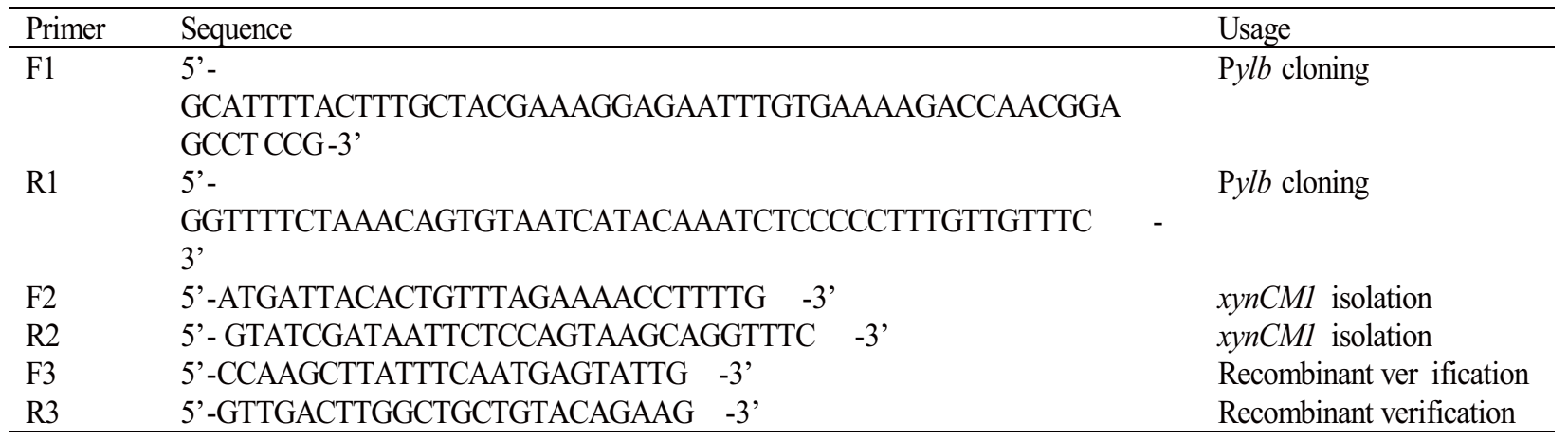

consisted of $10 \mathrm{~s}$ at $98^{\circ} \mathrm{C}, 30 \mathrm{~s}$ at $54^{\circ} \mathrm{C}$, and $5.5 \mathrm{~min}$ at $72{ }^{\circ} \mathrm{C}$. At last, a final extension was wrapped at $72{ }^{\circ} \mathrm{C}$ for $10 \mathrm{~min}$ to ensure the fragment elongation. A recombinant DNA was obtained and purified by GeneAid Gel/PCR DNA Fragments Kit [DF100, Geneaid Biotech, New Taipei City, Taiwan] with the method described previously prior to recombinant verification.

The verification was again performed by PCR using F3 and R3 primers (Table 1). The reaction mix in a total volume of $20 \mu \mathrm{L}$ was simply composed by $4 \mu \mathrm{L}$ $5 \times$ MyTaq Reaction Buffer, $1 \mu \mathrm{L} 10 \mu \mathrm{M}$ F3 and R3 primers, $1.5 \mu \mathrm{L}$ purified recombinant DNA, $0.25 \mu \mathrm{L}$ MyTaq HS DNA Polymerase [Bioline, London, UK], and $12.25 \mu \mathrm{LddH}_{2} \mathrm{O}$. A 30-cycles PCR was done under the condition: initial denaturation at $95{ }^{\circ} \mathrm{C}$ for $1 \mathrm{~min}$, denaturation at $95^{\circ} \mathrm{C}$ for $15 \mathrm{~s}$, annealing at $50{ }^{\circ} \mathrm{C}$ for 15 s, extension at $72{ }^{\circ} \mathrm{C}$ for $15 \mathrm{~s}$, and final extension at 72 ${ }^{\circ} \mathrm{C}$ for 10 min.

After it was verified, in-vitro ligation was proceeded by the incubation of $2 \mu \mathrm{L} 10 \times \mathrm{T} 4 \mathrm{DNA}$ Ligase, $16 \mu \mathrm{L}$ PCR product, and $1 \mu \mathrm{L}$ T4 Polynucleotide Kinase [Promega, Madison, USA] at $37^{\circ} \mathrm{C}$ for $30 \mathrm{~min}$. After the first incubation finished, 1 $\mu \mathrm{L}$ T4 DNA Ligase [Thermo Fisher, Waltham, USA] was added and the incubation was prolonged at room temperature for $30 \mathrm{~min}$. To eliminate non-recombinant

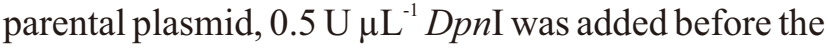
reaction was transformed into $E$. coli $\mathrm{DH} 5 \alpha$ competent cells. Verification of recombinant strains was done using both PCR (which the reaction described previously) and plasmid digestion with $M f e$ I.

Subcloning to B. subtilis DB104 and Recombinant Verification. Plasmid transformation in Bacillus was conducted using protoplasting method proposed by Chang and Cohen (1979). To make Bacillus competent cells, the wild-type B. subtilis DB104 strain was grown in LB media at $37{ }^{\circ} \mathrm{C}, 150$ $\mathrm{rpm}$, for overnight as a starter culture. It was inoculated into $20 \mathrm{ml}$ of Pennasay broth [Difco, Detroit, USA] until the $\mathrm{OD}_{600}$ reached $0.4-0.6$. The cell was harvested using centrifugation at $3800 \mathrm{rpm}, 4^{\circ} \mathrm{C}$, for 15 $\min$ [Gyrozen Centrifuge, $50 \mathrm{ml}$ rotor]. The protoplasts were formed after 2-h incubation at $37{ }^{\circ} \mathrm{C}$ in SMMP solution ( $0.5 \mathrm{M}$ sucrose, $0.02 \mathrm{M}$ maleic acid, $0.02 \mathrm{M}$ $\mathrm{MgCl} 2.6 \mathrm{H}_{2} \mathrm{O}$, and 3.5\% Pennasay powder) containing freshly-added $2 \mathrm{mg} \mathrm{mL}^{-1}$ lysozyme [Sigma-Aldrich, St. Louis, USA]. It went under several steps of washing before a final $1.5 \mathrm{~mL}$ of SMMP solution was gently added to resuspend cell pellets for plasmid transformation.

The DNA plasmid was prepared using a doublestrength SMM solution (1 M sucrose, $0.04 \mathrm{M}$ maleic acid, and $\left.0.04 \mathrm{M} \mathrm{MgCl}_{2} \cdot 6 \mathrm{H}_{2} \mathrm{O}\right)$ about 1:1 ratio of DNA and solution volume in a total of $50 \mu \mathrm{l}$. All of DNA mixture was added to $0.5 \mathrm{ml}$ protoplast suspension before the addition of $1.5 \mathrm{ml} 40 \%$ PEG6000 in SMM Solution ( $0.5 \mathrm{M}$ sucrose, $0.02 \mathrm{M}$ maleic acid, and 0.02 $\mathrm{M} \mathrm{MgCl}_{2} \cdot 6 \mathrm{H}_{2} \mathrm{O}$ ). The suspension was incubated for 2 $\mathrm{min}$ at room temperature. About $5 \mathrm{ml}$ of SMMP Solution was added prior to cell separation by centrifugation at $2900 \mathrm{rpm}, 4{ }^{\circ} \mathrm{C}$, for $10 \mathrm{~min}$. The cell pellet was resuspended by $1 \mathrm{ml}$ of SMMP Solution once again and incubated at $37^{\circ} \mathrm{C}$ for $1.5 \mathrm{~h}$ with 100 rpm agitation. About $500 \mu \mathrm{L}$ of cell suspension was spread on DM3 agar (0.5 M sodium succinate, $0.5 \%$ casamino acid, $0.5 \%$ yeast extract, $0.35 \% \mathrm{~K}_{2} \mathrm{HPO}_{4}$, $0.15 \% \mathrm{KH}_{2} \mathrm{PO}_{4}, 0.5 \%$ glucose, $0.02 \mathrm{M} \mathrm{MgCl}_{2} .6 \mathrm{H}_{2} \mathrm{O}$, $0.01 \% \mathrm{BSA}$, and $1 \%$ agar) containing $5 \mu \mathrm{g} / \mathrm{ml}$ erythromycin and the growth of recombinant colonies could be seen after 2 days incubation at $37^{\circ} \mathrm{C}$. We then selected the positive recombinant colonies by performing colony PCR and plasmid extraction for Bacillus as described by Voskuil and Chambliss (1995). Recombinant xylanase activity was checked qualitatively by measuring the ratio of clear zone diameter to bacterial colony diameter (in $\mathrm{cm}$ ) after $24 \mathrm{~h}$ of incubation on $\mathrm{LB}$ agar $\mathrm{pH} 7$ and $\mathrm{pH} 9$ in the presence 
of $2 \%(\mathrm{w} / \mathrm{v})$ beechwood xylan. Non-recombinant $B$. subtilis DB104 was used as negative control.

Plasmid Extraction of Recombinant $B$. subtilis DB104. The erythromycin-resistant transformant $B$. subtilis DB104 were selected and cultured in LB media containing erythromycin $\left(5 \mu \mathrm{g} \mathrm{mL}{ }^{-1}\right)$ under $37{ }^{\circ} \mathrm{C}$ at $150 \mathrm{rpm}$ agitation. Plasmid isolation performed with SET buffer (Voskuil and Chambliss 1993) after centrifugation at $12,000 \mathrm{rpm}$ at $4{ }^{\circ} \mathrm{C}$ for $5 \mathrm{~min}$ to obtain cell pellet. The cell pellet resuspended in $200 \mu \mathrm{L}$ in SET buffer (25\% sucrose, 0.05 M EDTA, 0.05 M Tris$\mathrm{HCl} \mathrm{pH} \mathrm{8)} \mathrm{containing} 5 \mathrm{mg} \mathrm{mL}^{-1}$ lysozyme and incubated at $37{ }^{\circ} \mathrm{C}$ for $10 \mathrm{~min} .0 .2 \mathrm{~N} \mathrm{NaOH}$ and $1 \%$ SDS was added to the suspension and flipped until clear. $5 \mathrm{M}$ of cold $\mathrm{KCOOH}$ was added and homogenized, then centrifuged. $650 \mu \mathrm{L}$ of cold phenol:chloroform:isoamyl-alcohol (25:24:1) was added to $750 \mu \mathrm{L}$ of supernatant and homogenized by vortexing at full speed. Aqueous phase from the suspension was obtained by centrifugation. $620 \mu \mathrm{L}$ of aqueous phase was obtained and $620 \mu \mathrm{L}$ of chloroform:isoamyl-alcohol (24:1) was added to suspension and homogenized by vortexing at full speed. The suspension was then centrifuged and 550 $\mu \mathrm{L}$ of aqueous phase was moved to new microtube. 550 $\mu \mathrm{L}$ of cold isopropanol was added, homogenized, and centrifuged. $1 \mathrm{~mL}$ of alcohol $70 \%$ was added to the pellet and centrifuged at $12000 \mathrm{rpm}$ at $4{ }^{\circ} \mathrm{C}$ for $5 \mathrm{~min}$. The pellet DNA was then resuspended in $\mathrm{ddH} 2 \mathrm{O}$ with RNAse $\left(20 \mu \mathrm{g} \mathrm{mL}^{-1}\right)$.

Growth Curve Observation and Media Formulation. Recombinant B. subtilis DB104 harboring pSKE194-Pylb-alkxynCM1-inlip was cultured overnight in $10 \mathrm{~mL}$ of LB media in the presence of $5 \mu \mathrm{g} \mathrm{mL} L^{-1}$ erythromycin under $37^{\circ} \mathrm{C}$ at 150 rpm agitation. Two percent of the culture was then used to inoculate $100 \mathrm{~mL}$ of fresh LB media containing the same antibiotic under $37^{\circ} \mathrm{C}$ at $150 \mathrm{rpm}$ agitation for 24 h. Samples were taken every $2 \mathrm{~h}$ to observe bacterial cell density by measuring $\mathrm{OD}_{600}$ then plotted against time to obtain bacterial growth curve.

Media optimization strategy used to achieve highcell density with modification in yeast extract and glucose concentration. Several media used were based on LB and SOC media. LB media (1\% tryptone, $0.5 \%$ yeast extract, $1 \% \mathrm{NaCl}$ ) and $2 \mathrm{X} \mathrm{LB}$ media with 2-fold concentration recipe containing $5 \mu \mathrm{g} \mathrm{mL}^{-1}$ erythromycin [Sigma-Aldrich, St. Louis, USA] were used. Soybean flour media used as an alternative source of nitrogen containing $1.89 \%(\mathrm{w} / \mathrm{v})$ soybean flour and $1 \% \mathrm{NaCl}$. For glucose optimization, SOC media-based were used containing $1 \%$ and $5 \%(\mathrm{w} / \mathrm{v})$ glucose for each variation.

Xylanase Assay. Xylanase activity was assayed using dinitrosalicylic acid (DNS) to measure reducing sugar produced from xylan hydrolysis (Bailey et al. 1992; Miller 1959) in triplicate with some modifications. Crude enzyme was obtained from culture supernatant after centrifugation at $12000 \mathrm{rpm}$ at $4{ }^{\circ} \mathrm{C}$ for $5 \mathrm{~min} .50 \mu \mathrm{L}$ of supernatant was added to 450 $\mu \mathrm{L}$ xylan substrate containing $0.5 \%(\mathrm{w} / \mathrm{v})$ beechwood xylan in $0.5 \mathrm{M}$ Tris-HCl buffer $\mathrm{pH} 9$. The reaction takes place at $70{ }^{\circ} \mathrm{C}$ for $5 \mathrm{~min}$ at $300 \mathrm{rpm}$ using a thermoshaker. After incubation, $750 \mu \mathrm{L}$ of DNS reagent ( $1 \%$ dinitrosalicylic acid, $0.2 \%$ phenol, $0.05 \%$ sodium sulfite, $1 \%$ sodium hydroxide, and $20 \%(\mathrm{w} / \mathrm{v})$ potassium sodium tartrate) was added immediately. As for blank, $50 \mu \mathrm{L}$ of sample was added after DNS addition. All the samples and blanks were boiled for 5 $\mathrm{min}$ and let cool to room temperature. $250 \mu \mathrm{L}$ of water was added, homogenized, and reducing sugar released was measured at $540 \mathrm{~nm}$. Standard curve obtained from xylose suspension ranging from $0 ; 0.2 ; 0.4 ; 0.6 ; 0.8$; and $1 \mathrm{mg} \mathrm{mL}{ }^{-1}$ using the same protocol. Xylanase activity stated in Unit (U) defined as the amount of enzyme releasing $1 \mu \mathrm{mol}$ of reducing sugar per minute under appropriate assayed condition.

\section{RESULTS}

Pylb Cloning and Verification. DNA fragment of $256 \mathrm{bp}$ coding for $P y l b$ promoter was integrated into pSKE194-natprom-alkxynCM1-inlip by PCR cloning resulting an 8757 bp recombinant plasmid (Fig 2A). The insertion can occur because of the presence of 56 bp of overlapping region in both ends of $\mathrm{P} y l b$ fragments so that they annealed into the backbone and promoting the formation of new recombinant plasmid in the next cycle of amplification. As depicted in the figure, the gene cassette was constructed of three genes with the position of $\mathrm{P} y l b$ promoter between the native promoter and $x y n C M 1$ gene. The flanking regions of lipase locus at both $5^{\prime}$ and $3^{\prime}$ ends were intended for further experiments with chromosomal integration and could be used for the verification of positive recombinants (Fig 2B).

The positive recombinants of $E$. coli $\mathrm{DH} 5 \alpha$ and $B$. subtilis DB104 were confirmed by PCR using F3 and $\mathrm{R} 3$ primer set and proved to be harboring the targeted gene Pylb (200 bp) within a 2061 bp gene cassette (Fig 3C). This result was also supported by $M f e$ I digestion which cut the plasmid into two fragments of $7456 \mathrm{bp}$ 


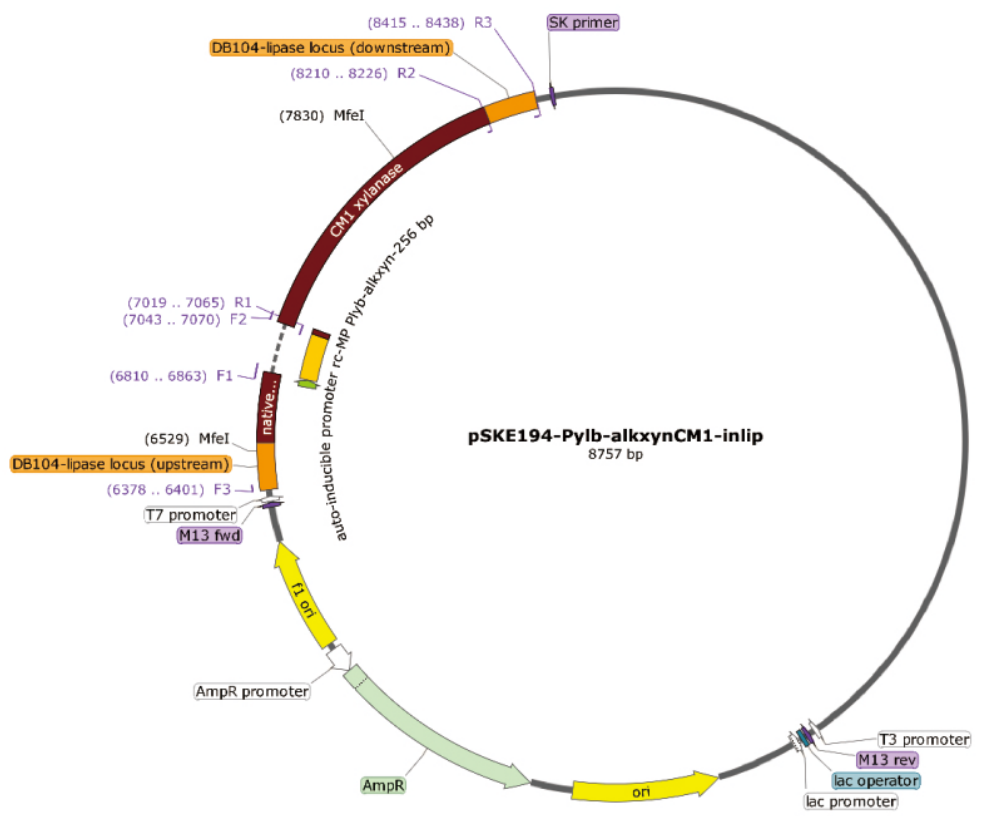

(a)

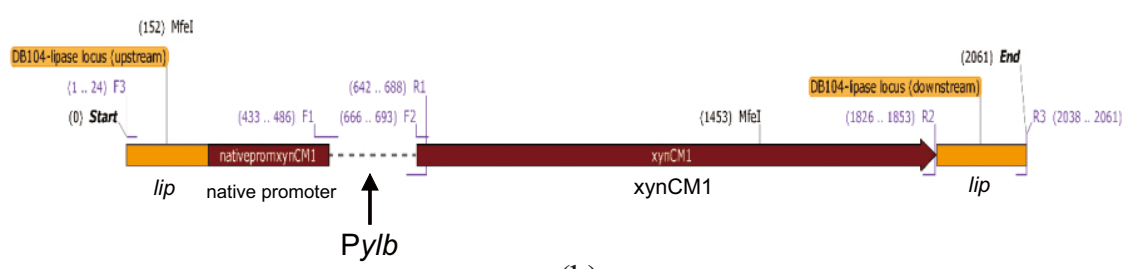

(b)

Fig 2 The constructed plasmid and gene cassette of Pylb. (a) The whole construct of recombinant plasmid pSKE194-Pylb-alkxynCM1-inlip (8757 bp) and its features; (b) A 2061 gene cassette containing 200 bp Pylb fragment.

and $1301 \mathrm{bp}$ after 1 -hour incubation at $37^{\circ} \mathrm{C}$ that were notably delineated from the negative one. According to the vector map, MfeI digestion of recombinant plasmid generated 2 fragments of 1.3 and $7.5 \mathrm{~kb}$, while control with lack of target gene formed smaller bands of 1.1 and $7.5 \mathrm{~kb}$ corresponding to the result (Fig 3D). Three out of four potential B. subtilis DB104 transformants were identified as positive clones, however, only one clone (R3) was carried out for further experiments of protein expression and media formulation.

Qualitative Assay of Xylanase. Qualitative assay of xylanase produced by recombinant $B$. subtilis performed in LB xylan media $\mathrm{pH} 7$ and $\mathrm{pH} 9$ to detect alkaline xylanase and compared to B. subtilis DB104 wild-type. Clear zone ratio 2.00 surrounding recombinant $B$. subtilis colony in LB media $\mathrm{pH} 9$ (Fig 4D) showed alkaline xylanase activity and no distinct clear zone observed in LB media $\mathrm{pH} 7$ (Fig 4C). As control, B. subtilis DB104 wild-type grown on LB media pH 7 (Fig 4A) showed distinct xylanase activity around the colony with clear zone ratio 1.40 , while no clear zone detected in LB media pH 9 (Fig 4B).
Growth Curve and Media Optimization to Achieve High Cell-Density. The growth curve of recombinant xylanase-producing $B$. subtilis was investigated to determine when the enzyme was highlyproduced. Growth curve observed in LB media for $24 \mathrm{~h}$ with $B$. subtilis DB104 wild-type as control bacteria (Fig 5). Both wild-type and recombinant $B$. subtilis entered the $\log$ phase after $2 \mathrm{~h}$ of cultivation and the recombinant $B$. subtilis reached the cell density peak after $9 \mathrm{~h}$, while wild-type strain entered the stationary phase after 11 h. B. subtilis wild-type reached higher cell density than recombinant $B$. subtilis. Based on the growth curve, samples were taken at $5 \mathrm{~h}$ (log phase), $9 \mathrm{~h}$ (late log phase), $14 \mathrm{~h}$ (stationary phase), and $24 \mathrm{~h}$ (late stationary phase) after inoculation to determine xylanase activity.

All samples taken from recombinant and wild-type B. subtilis exhibit xylanase activity measured by DNS method. Both supernatant from recombinant and wildtype bacteria shows higher level of enzyme expression taken from 24-h supernatant culture (Table 2). Moreover, recombinant xylanase (R3) performed 2.5fold higher level of enzyme expression $\left(23.874 \mathrm{U} \mathrm{mL}^{-1}\right)$ 


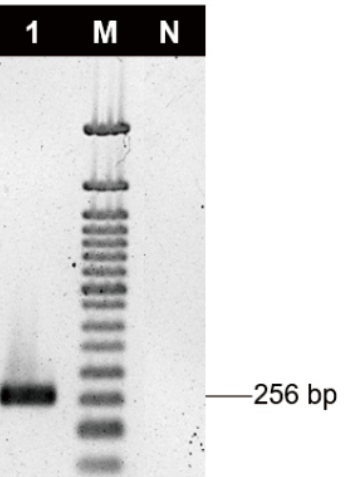

(a)

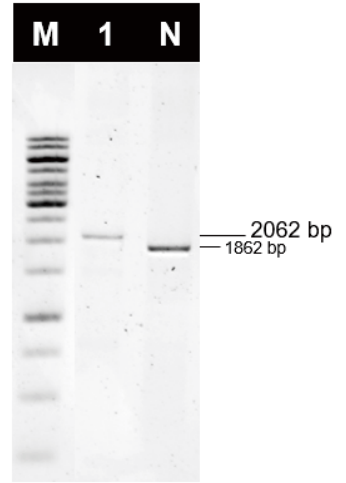

(c)

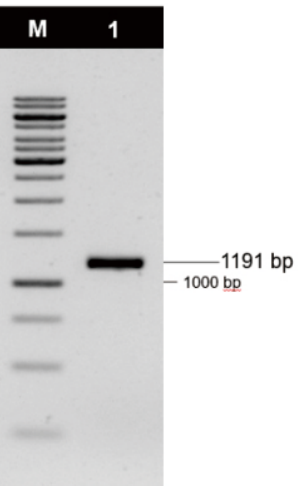

(b)

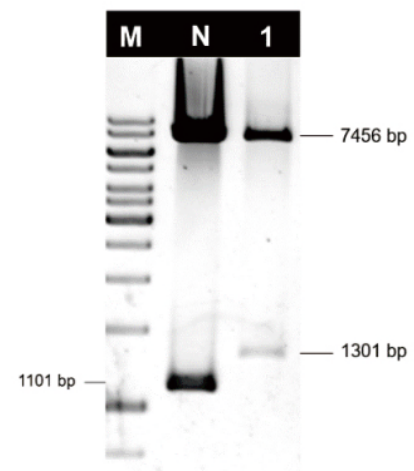

(d)

Fig 3 The insertion and verification of Pylb gene. (a) PCR amplification of 1) $256 \mathrm{bp}$ Pylb gene and its N) negative control from B. subtilis DB104; (b) PCR amplification of 1) 1191 bp assisting-fragments xynCM1 from gDNA of $B$. halodurans CM1; (c) Colony PCR verification of positive clones harboring pSKE194-PylbalkxynCM1-inlip with its N) negative control of pSKE194-natprom-alkxynCM1-inlip (no inserted Pylb gene); and (d) $\mathrm{MfeI}$ digestion of 1) positive recombinant plasmid and its N) negative control after 1-hour incubation at $37^{\circ} \mathrm{C}$.
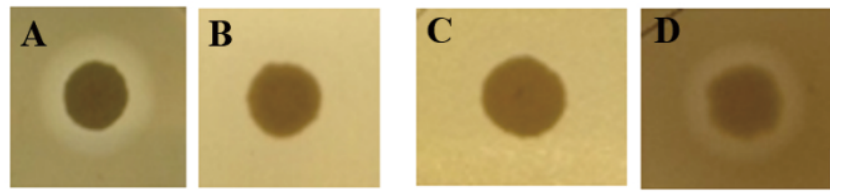

Fig 4 Qualitative assay of xylanase from B. subtilis DB104 wild-type grown on LB in the presence of $2 \%$ (w/v) of beechwood xylan pH 7 (A); LB-xylan pH 9 (B); recombinant B. subtilis harboring pSKE194-PlybalkxynCM1-inlip grown on LB-xylan $\mathrm{pH} 7$ (C) and LB-xylan $\mathrm{pH} 9$ (D).

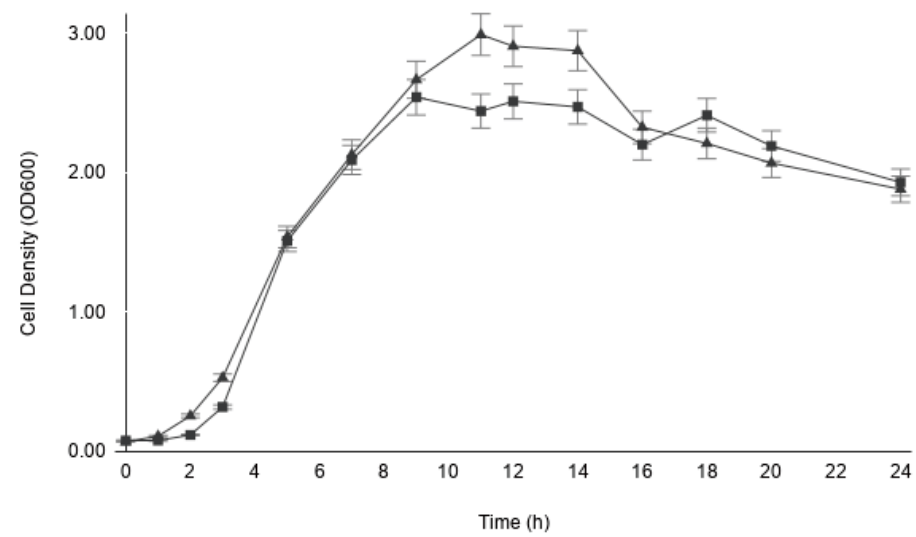

Fig 5 B. subtilis DB104 growth curve in LB media at $37^{\circ} \mathrm{C}$. Wild-type B. subtilis $(\boldsymbol{\Delta})$ showed higher peak cell density than Pylb promoter-dependent recombinant xylanase ( $\mathbf{\square})$. 
Table 2 Xylanase activity measured by DNS method from supernatant culture of wild-type and recombinant $B$. subtilis DB104

\begin{tabular}{ccc}
\hline \multirow{2}{*}{ Time (-hour) } & \multicolumn{2}{c}{ Xylanase activity $\left(\mathrm{U} \mathrm{mL}^{-1}\right)$} \\
\cline { 2 - 3 } & $\mathrm{R} 3$ & wild-type \\
\hline 5 & 6.664 & 4.911 \\
9 & 10.499 & 6.328 \\
14 & 18.080 & 8.769 \\
24 & 23.874 & 9.435 \\
\hline
\end{tabular}

Table 3 Cell density $\left(\mathrm{OD}_{600}\right)$ and xylanase activity $\left(\mathrm{U} \mathrm{mL}^{-1}\right)$ of recombinant $B$. subtilis from different media compared to controls

\begin{tabular}{l|cc|cc|cc}
\hline \multicolumn{1}{c|}{ Media } & \multicolumn{2}{|c|}{ wild-type } & \multicolumn{2}{c|}{$\begin{array}{c}\text { xynCM1 } \\
\text { with native promoter }\end{array}$} & \multicolumn{2}{c}{$\begin{array}{c}\text { xynCM1 } \\
\text { with Pylb promoter }\end{array}$} \\
& \multicolumn{2}{c|}{\begin{tabular}{cc|cc|cc} 
Activity \\
$\left(\mathrm{U} \mathrm{mL}^{-1}\right)$
\end{tabular}} & $\mathrm{OD}_{600}$ & $\begin{array}{c}\text { Activity } \\
\left(\mathrm{U} \mathrm{mL}^{-1}\right)\end{array}$ & $\mathrm{OD}_{600}$ & $\begin{array}{c}\text { Activity } \\
\left(\mathrm{U} \mathrm{mL}^{-1}\right)\end{array}$ \\
\hline LB & 1.905 & 2.871 & 2.205 & 26.944 & 2.710 & 21.598 \\
2X LB & 5.050 & 20.600 & 5.680 & 73.192 & 5.025 & 81.461 \\
Soybean flour media & - & 3.978 & - & 13.995 & - & 31.299 \\
SOC & 7.040 & 29.436 & 6.250 & 22.504 & 5.720 & 60.893 \\
SOC (with 1\% glucose) & 3.645 & 15.207 & 2.335 & 10.949 & 2.930 & 19.304 \\
SOC (with 5\% glucose) & 3.995 & 61.551 & 3.980 & 28.937 & 4.365 & 47.937 \\
SOB (with starter SOC) & 5.965 & 3.294 & 4.525 & 24.508 & 2.200 & 24.766 \\
\hline
\end{tabular}

than wild-type xylanase from $B$. subtilis $\left(9.435 \mathrm{U} \mathrm{mL}^{-1}\right)$. It also reached almost 4 times higher than log-phase recombinant xylanase $\left(6.664 \mathrm{U} \mathrm{mL}^{-1}\right)$.

To determine the effect of both carbon and nitrogen supplementation in media, yeast extract and glucose were used for B. subtilis growth with LB media and SOC media as the base media (Table 3). Not only xylanase activity, cell density was also measured by spectrophotometer at $600 \mathrm{~nm}\left(\mathrm{OD}_{600}\right)$. The expression of recombinant xylanase produced by clone R3 harbouring $\mathrm{P} y l b$ promoter was compared with wildtype $B$. subtilis and recombinant $B$. subtilis carrying the same xylanase gene but with the native promoter as controls (Table 3 ).

LB media with a 2-fold recipe (2X LB) used as the first step to determine the effect of higher content of yeast extract addition on the $B$. subtilis growth. Cell density at stationary phase was increased 2-fold higher than other bacteria grown on LB media, with $\mathrm{OD}_{600}$ 5.025 for recombinant B.subtilis harbouring $\mathrm{P} y l b$ promoter. Recombinant xylanase under Pylb promoter control reached the highest result in enzyme activity (81.461 $\mathrm{U} \mathrm{mL}^{-1}$ ), almost 4-fold higher than grown on LB media. It is also higher than xylanase produced by wild-type $B$. subtilis xylanase $\left(20.600 \mathrm{U} \mathrm{mL}^{-1}\right)$ and recombinant xynCM1 with native promoter $(73.192 \mathrm{U}$ $\mathrm{mL}^{-1}$ ). Soybean flour media as an alternative source to supply nitrogen requirement in $B$. subtilis growth gave no better result in maintaining high activity of recombinant xylanase, even though recombinant xylanase under Pylb promoter control remains the highest activity among others.

SOC media were used with different concentrations of glucose (1\% and 5\%) and compared to original SOC media ( $20 \mathrm{mM}$ of glucose). Biomass yield from high glucose content in SOC media measured by cell density $\left(\mathrm{OD}_{600}\right)$ revealed a decreasing cell density compared to original SOC media. Meanwhile, wild-type and recombinant B. subtilis grown in SOB media with SOC media as former media starter exhibited higher cell density compared to excess glucose media, even though it did not surpass the cell density from original SOC media. Recombinant xylanase under $\mathrm{P} y \mathrm{lb}$ promoter control produced in SOC media with original concentration of glucose $(20 \mathrm{mM})$ showed highest xylanase activity also among other variety of SOC media.

\section{DISCUSSION}

The Pylb gene (256 bp) from B. subtilis was successfully inserted into the plasmid by the assistance of megaprimer of the same $1191 \mathrm{bp}$ xylanase gene that was already incorporated in it. The cloning method this study used was slightly different from the original RF cloning in which only one megaprimer (as targeted gene) needed (Mathieu et al. 2014). In our experiment we used two megaprimers, one was our Pylb gene which possessed flanking regions of homology with the assisting-gene so that in the first cycle of PCR both 
could anneal as one joint-fragment (total size of 1447 bp). This leads to relatively easier insertion of jointfragment into the plasmid even in low annealing temperature because the assisting-gene has extended homologous region with the vector at $5^{\prime}$ end. No additional pair of primers was used in the reaction for cloning, resulting linear amplification not exponential (Ulrich et al. 2012; Mathieu et al. 2014).

$\mathrm{P} y l b$ promoter is an auto-inducible promoter which promotes gene expression from late log phase to stationary phase with no requirements of inducer ( $\mathrm{Yu}$ et al. 2015). Insertion of this promoter is necessary to upgrade recombinant xylanase production from recombinant $B$. subtilis DB104. This bacteria itself (wild-type) performed xylanase activity from encoded gene in its chromosome (Helianti et al. 2016) and observed in $\mathrm{pH} 7$, while recombinant xylanase from $B$. subtilis harbouring pSKE194-Pylb-alkxynCM1-inlip performed alkaline xylanase as the gene originated from alkalothermophilic B. halodurans CM1 (Wibowo et al. 2016). This was confirmed by qualitative assay of recombinant xylanase which shown xylanase activity from recombinant bacteria in xylan plate media $\mathrm{pH} 9$. In addition, recombinant xylanase were produced in increasing activity corresponding to bacterial growth curve and highly produced in stationary phase $(24 \mathrm{~h}$ after inoculation).

As stated above, gene expression under Pylb promoter highly expressed along with increasing cell density (Yu et al. 2015). In order to obtain a higher cell density, media composition needs to be optimized. $B$. subtilis biomass obtained at the end of the logarithmic phase increased following the increasing quantities of yeast extract added to the media. Specific growth rate of B. subtilis supplemented with $0.8 \%(\mathrm{w} / \mathrm{v})$ of yeast extract increased up to 6-fold and no further significant change above that quantity (Romero-Garcia et al. 2009). In this research, $2 X$ LB media contained $1 \%$ $(\mathrm{w} / \mathrm{v})$ of yeast extract and only produced a 2 -fold increase in cell density. The presence of yeast extract was confirmed to affect $B$. subtilis growth and increase xylanase activity if a certain amount of yeast extract were added. Furthermore, recombinant xylanase under Pylb promoter control constantly expressed at a higher level compared to other xylanases even if the media were switched to an alternative source of nitrogen.

Glucose supplementation on batch fermentation of $B$. subtilis obtained higher cell dry weight, with optimum glucose concentration identified as 3.07\% (w/v) (Zhong et al. 2014). According to the results in this experiment, excess carbon source in modified media did not enhance biomass yield and xylanase expressed from recombinant $B$. subtilis was not higher than in original SOC media with $20 \mathrm{mM}$ glucose. It turned out that excess energy source in media (usually carbon source) exhibited a high rate of carbon consumption and low energetic growth efficiency. High carbon source in the growth of microorganisms generates uncoupling of anabolism and catabolism thus lead to variety of energy spilling reaction and metabolic shifting in electron pathway to less efficient called overflow metabolism (Dauner et al. 2001). In contrast, energy limitation generates catabolism coupling to anabolism so higher biomass is achieved (Russel and Cook. 1995). From this research, maintaining glucose concentration at certain amount while increasing nitrogen content might be able to express a higher level of recombinant xylanase with $\mathrm{P} y l b$ promoter control in B. subtilis DB104.

\section{REFERENCES}

Bailey MJ, Biely P, Poutanen K. 1992. Interlaboratory testing of methods for assay of xylanase activity. J Biotechnol. 23(3):257-270. doi: 10.1016/0168-1656(92)90074-J.

Cui H, Wang L, Yu Y. 2015. Production and characterization of alkaline protease from a high yielding and moderately halophilic strain of SD11 marine bacteria. J Chem. doi: $10.1155 / 2015 / 79830$.

Chang S, Cohen SN. 1979. High frequency transformation of Bacillus subtilis protoplasts by plasmid DNA. Mol Gen Genet MGG. 168(1):111-115. doi : 10.1007/BF00267940.

Dauner M, Storni T, Sauer UW. 2001. Bacillus subtilis metabolism and energetics in carbon-limited and excesscarbon chemostat culture. J Bacteriol. 183(24):73087317. doi: 10.1128/JB.183.24.7308-7317.2001.

Einav T, Phillips R. 2019. How the avidity of polymerase binding to the $-35 /-10$ promoter sites affects gene expression. Proc Natl Acad Sci. 116(27):13340-5. doi: 10.1073/pnas.1905615116.

Gupta U, Kar R. 2008. Optimization and scale up of cellulase free endo xylanase production by solid state fermentation on corn cob and by immobilized cells of a thermotolerant bacterial isolate. Jordan J Biol Sci (JJBS). 1(3):3129 3134.

Haniyya, Mulyawati L, Nurhayati N, Helianti I. 2019. Utilization of thermo-sensitive plasmid for chromosomal integration of Bacillus halodurans CM1 thermoalkalophilic xylanase gene with its native promoter in Bacillus subtilis DB104. J Chem Biol Phys Sci. 9(3):1319-1331. doi: 10.24214/jcbps.B.9.3.141931.

Helianti I, Ulfah M, Nurhayati N, Suhendar D, Finalissari AK, 
Wardani AK. 2016. Production of xylanase by recombinant Bacillus subtilis DB104 cultivated in agroindustrial waste medium. HAYATI J Biosci. 23(3):125-131. doi: 10.1016/j.hjb.2016.07.002.

Helianti I, Ulfah M, Noer S, Nurhayati N, Saefudin E. 2018. Cloning and expression of alkalophilic xylanase gene from an Indonesia local Bacillus halodurans CM1 in Escherichia coli and its application on deinking process of waste paper. Malaysian J Microbiol. 1(7):655-662. doi: $10.21161 / \mathrm{mjm} .114217$

Kawamura F, Doi RH. 1984. Construction of a Bacillus subtilis double mutant deficient in extracellular alkaline and neutral proteases. J Bacteriol. 160(1):442-444.

Mageshwaran V, Inmann F, Holmes LD. 2014. Growth kinetics of Bacillus subtilis in lignocellulosic carbon sources. Int J Microbiol Res. 6:570-574.

Mathieu J, Alvarez E, Alvarez PJJ. 2014. Recombinationassisted megaprimer (RAM) cloning. MethodsX. 1(2014):23-29. doi: 10.1016/j.mex.2014.05.001.

Meissner L, Kauffmann K, Wengeler T, Mitsunaga H, Fukusaki E, Büchs J. 2015. Influence of nitrogen source and $\mathrm{pH}$ value on undesired poly ( $\gamma$-glutamic acid) formation of a protease producing Bacillus licheniformis strain. J Ind Microbiol Biotechnol. 42(9):1203-15. doi: 10.1007/s10295-015-1640-7.

Mekler V, Minakhin L, Kuznedelov K, Mukhamedyarov D, Severinov K. 2012. RNA polymerase-promoter interactions determining different stability of the Escherichia coli and Thermus aquaticus transcription initiation complexes. Nucleic Acids Res. 40(22):1135211362. doi: 10.1093/nar/gks973.

Meyers A, Furtmann C, Gesing K, Tozakidis IE, Jose J. 2019. Cell density-dependent auto-inducible promoters for expression of recombinant proteins in Pseudomonas putida. Microbial Biotechnol. 12(5):1003-1013. doi: 10.1111/1751-7915.13455.

Miller GL. 1959. Use of dinitrosalicylic acid reagent for determination of reducing sugar. Anal Chem. 31(3):426431. doi: 10.1021/ac60147a030.

Romero-Garcia S, Hernández-Bustos C, Merino E, Gosset G, Martinez A. 2009. Homolactic fermentation from glucose and cellobiose using Bacillus subtilis. Microbial Cell Factories. 8(1):23. doi: 10.1186/1475-2859-8-23.

Russell JB, Cook GM. 1995. Energetics of bacterial growth: balance of anabolic and catabolic reactions. Microbiol Mol Biol Rev. 59(1):48-62.

Schumann W. 2007. Production of recombinant proteins in Bacillus subtilis. Adv Appl Microbiol. 62:137-89. doi:
10.1016/S0065-2164(07)62006-1.

Trung NT, Hung NM, Thuan NH, Canh NX, Schweder T, Jürgen B. 2019. An auto-inducible phosphate-controlled expression system of Bacillus licheniformis. BMC Biotechnol. 19(1):3. doi: 10.1186/s12896-018-0490-6.

Ulfah M, Helianti I, Wahyuntari B, Nurhayati N. 2012. Characterization of a new thermoalkalophilic xylanaseproducing bacterial strain isolated from Cimanggu hot spring, West Java, Indonesia. Microbiol Indones. 5(3):7. doi: $10.5454 / \mathrm{mi} .5 .3 .7$.

Ulrich A, Andersen KR, Schwartz TU. 2012. Exponential megapriming PCR (EMP) cloning-seamless DNA insertion into any target plasmid without sequence constraints. PLOS ONE 8(9):1-8. doi: 10.1371/journal.pone.0053360.

Voskuil MI, Chambliss GH. 1993. Rapid isolation and sequencing of purified plasmid DNA from Bacillus subtilis. Appl Environ Microbiol. 59(4):1138-1142.

Watzlawick H, Altenbuchner J. 2019. Multiple integration of the gene ganA into the Bacillus subtilis chromosome for enhanced $\beta$-galactosidase production using the CRISPR/Cas9 system. AMB Express. 9(1):158. doi: 10.1186/s13568-019-0884-4.

Wenzel M, Müller A, Siemann-Herzberg M, Altenbuchner J. 2011. Self-inducible Bacillus subtilis expression system for reliable and inexpensive protein production by highcell-density fermentation. Appl Environ Microbiol. 77(18):6419-6425. doi: 10.1128/AEM.05219-11.

Westers L, Westers H, Quax WJ. 2004. Bacillus subtilis as cell factory for pharmaceutical proteins: a biotechnological approach to optimize the host organism. Biochim Biophys Acta. 1694(1-3):299-310. doi: 10.1016/j.bbamcr.2004.02.011.

Wibowo S, Helianti I, Suryani A, Wahyuntari B. 2016. Application of response surface method in optimization of medium composition for xylanase production by Bacillus halodurans CM1 in submerged fermentation. Microbiol Indones. 10(3):5. doi: 10.5454/mi.10.3.5.

Yu X, Xu J, Liu X, Chu X, Wang P, Tian J, Wu N, Fan Y. 2015. Identification of a highly efficient stationary phase promoter in Bacillus subtilis. Sci Rep. 5:18405. doi: 10.1038/srep18405.

Zhong J, Zhang X, Ren Y, Yang J, Tan H, Zhou J. 2014. Optimization of Bacillus subtilis cell growth effecting jiean-peptide production in fed batch fermentation using central composite design. Electron J Biotechnol. 17(3):132-136. doi: 10.1016/j.ejbt.2014.04.010. 